\title{
Does the EU Need a European Migration and Protection Agency?
}

\author{
in honour of Professor Guy Goodwin-Gill
}

\section{Jean Monnet Professor ad personam Elspeth Guild, Queen Mary University of London, Radboud Universiteit Nijmegen, (NL)}

In 2015, Guy S Goodwin-Gill began to promote the idea that Europe, and more particularly the European Union (EU), needs a new institution: a European Migration and Protection Agency. ${ }^{1}$ In this article, I will examine the state of the EU regarding asylum and analyse the options available for either a new competence to an existing institution or the space for a new one. It was in this context that Goodwin-Gill argued that, since the EU is based on common values and shares international obligations, it was disingenuous to suggest that refugees in EU Member States were the responsibility, exclusively, of those states individually. The intensification in 2015 of the regional war in Syria and Iraq resulted in millions of Syrian and Iraqi refugees seeking asylum in Europe. The neighbouring countries in which many of them have been living for over four years already have become less hospitable. For instance, Lebanon, which has hosted more than 3.2 million Syrian refugees,${ }^{2}$ introduced visa requirements for Syrians in early $2015 .{ }^{3}$ The pressure on Turkey increased as a result. From the summer of 2015, the Aegean sea border between Turkey and Greece became the new flash point for the arrival of people seeking international protection. The response of EU states and candidate states ${ }^{4}$ in the Western Balkans in 2015 was been substantially criticised as insufficient, and UNHCR called for a more coordinated response. ${ }^{5}$

There was a wide range of proposals for new action by the EU institutions and package after package of proposed reforms in 2015. Two policy commitments of the EU were put into question - the Dublin system of allocation of responsibility for asylum seekers primarily on the basis of the first country through which they entered the EU as a whole, and the Schengen area - an area in Europe without internal border controls on persons moving between states. As refugees travelled across the EU searching for a hospitable place to seek refuge, the Dublin system became irrelevant and the option of border controls as a way to deter refugees from entering states became increasing attractive to some countries. ${ }^{6}$

Goodwin-Gill identified the need for an institution with specific responsibility to fulfil collectively and to implement the Member States individual obligations to refugees, and migrants. He noted that

\footnotetext{
${ }^{1}$ Guy Goodwin Gill, 'Regulating "Irregular" Migration: International Obligations and International Responsibilities', Notes for a Presentation, University of Naples 'L'Orientale' 11 May 2015 and Keynote Address to the International Workshop, National and Kapodistrian University of Athens Faculty of Law, Friday, 20 March 2015.

2 UNHCR, 'Syrian Regional Refugee Response' Data UNHCR 2016 http://data.unhcr.org/syrianrefugees/country.php?id=122 accessed 25 April 2016.

${ }^{3}$ Hugh Naylor and Suzan Haidamous 'Syrian refugees become less welcome in Lebanon, as new entry rules take effect' Washington Post (Washington, 5 January 2015).

${ }^{4}$ All of the countries of the Western Balkans have applied for membership of the EU and currently enjoy the formal status of 'candidate countries'.

${ }^{5}$ UNHCR 'Over 1 million sea arrivals reach Europe' UNHCR 30 December 2015 http://www.unhcr.org/5683d0b56.html accessed 5 January 2016.

${ }^{6}$ Elspeth Guild, 'What is happening to the Schengen borders?' CEPS Paper in Liberty and Security in Europe 86 (2015).
} 
there are already a number of EU agencies - the European Asylum Support Office (EASO) and the Fundamental Rights Agency (FRA), in particular - which are charged with issues concerning refugee protection and migration. But in his view, while they can play a role in the monitoring for effective protection of the sorts of 'solutions' which the EU and its Member States have been contemplating, a more international approach is still needed.

The focus of this article is less on the enhanced coordinated international approach which GoodwinGill maintains is needed for the immediate crisis in the Middle East and more on the issues surrounding the creation of a new EU agency charged with ensuring real solidarity among the Member States and protecting refugees and migrants.

\section{The history and institutional structure of the EU regarding Refugees and Migrants}

The EU's Common European Asylum System (CEAS) grew out of the EU's project to abolish border controls between the Member States and to apply compensatory measures regarding common external border controls. ${ }^{7}$ An inherent component of this system was considered to be the development of the CEAS. It started from a fairly simple idea that Member States are entitled to determine in which Member State an individual is permitted to make his or her asylum application and developed from there to what is, in 2016, a system in crisis. This section addresses the framework within which the CEAS came into existence.

The four freedoms - free movement of goods, persons, services, and capital - are the foundation of the EU. From its inception in the early 1950s, these freedoms have driven and provided the basis for the consolidation of EU law. For the purposes of the CEAS, it is the freedom of movement of persons that provides the starting point. The first transitional period for the achievement of free movement of persons (in the form of workers and the self-employed) ended in 1968, which resulted in the development of the right through the interpretation of the treaty provisions, regulations, and directives designed to give it effect in the national courts and the Court of Justice of the EU. ${ }^{8}$ Three events in the 1980s had profound effects on the issue of scope. ${ }^{9}$ The first was the initial Schengen Agreement $1985^{10}$ where five Member States ${ }^{11}$ agreed to abolish all border controls on movement of persons between themselves. Implicit in this was the inclusion of third country nationals, including refugees and asylum seekers, as beneficiaries of the abolition of border controls on persons. This was rapidly followed by the Single European Act 1987, which included as an EU measure the abolition of intra-Member State border controls on the movement of goods, persons, services, and capital at the latest by 31 December 1992. Once again, the inclusion of third country nationals was implicit, and already the UK delegation raised questions about the continued legality of passport controls on persons entering the UK after 31 December $1992 .{ }^{12}$ It is worth remembering

\footnotetext{
7 Elspeth Guild 'The Europeanisation of Europe's asylum policy' [2006] IJRL 630-51.

8 Paul Minderhoud, and Nicos Trimikliniotis, Rethinking the Free Movement of Workers. The European Challenges ahead (Wolf Legal Publishers, 2009).

${ }^{9}$ This question was resolved in favour of EU citizens only in Case C-22/08 Vatsouras \& Koupatantze [2009] ECR I-4585.

${ }^{10}$ European Union, Agreement between the Governments of the States of the Benelux Economic Union, the Federal Republic of Germany and the French Republic on the gradual abolition of checks at their common borders, Schengen Agreement, 14 June 1985, Official Journal [2000] L 239 /13 - 18.

${ }^{11}$ Belgium, Germany, France, Luxembourg and the Netherlands.

${ }^{12}$ Andrew Moravcsik, 'Negotiating the Single European Act: national interests and conventional statecraft in the European Community.' [1991] IO 19-56.
} 
that the second and third enlargements of the EU had taken place by this time to include Greece (1981) and Portugal and Spain (1986). A further significant event was, of course, the fall of the Berlin Wall on 9 November 1989 and the end of the era of bipolarity. Movement of persons had played its part in this story, as East German nationals travelled in increasing numbers in August 1989 through Hungary to Austria to collect their West German passports and enjoy free movement of persons in the EU (though primarily they were interested in moving to the 'other' Germany). ${ }^{13}$ The fall of the Berlin Wall was preceded and followed by substantial increases in the numbers of asylum seekers coming to EU Member States seeking international protection. These numbers spiked in the 1990s during the Balkan wars that followed the dissolution of Yugoslavia and the dismemberment of the Soviet Union. ${ }^{14}$

The first European (but not EU) treaty that brought together the issue of refugees and the abolition of border controls was the Schengen Implementing Agreement $1990(\mathrm{CISA})^{15}$ - already far down the road of preparation before the Berlin Wall fell. In this treaty, the nuts and bolts of the Schengen system were set out including the abolition of intra-Schengen state border controls and a specific system for the allocation of asylum seekers to Member States. This approach to state responsibility towards people seeking international protection in an area without internal border controls on persons was based on the principle that borders are still effective regarding asylum seekers, and that states had an entitlement to pool responsibility for them as those states themselves determined. These basics were transposed into the Dublin Agreement 1990. ${ }^{16} \mathrm{EU}$ Member States began to sign up to the Schengen system and by the end of the decade all of them were parties except Ireland and the UK which insisted on their island particularity to justify the continuation of border controls on persons coming from other Member States to their territory. However, both countries did participate in the Dublin Agreement which was more or less a carbon copy of the asylum section of CISA. This decade also include the fourth enlargement of the EU to include Austria, Finland, and Sweden (1995). CISA was absorbed into EU law in 1999 which gave competence and obligation to the EU to adopt the CEAS.

Two regional and/or civil wars framed the development of the CEAS. First, the disintegration of the former Yugoslavia from 1992 to 1995 resulted in hundreds of thousands of refugees fleeing the region, often to Europe and particularly to Germany. ${ }^{17}$ The sense that Germany had been left to cope with the consequences of refugee flight from the Western Balkan region was an important factor in the inclusion of asylum in the Amsterdam Treaty of 1999. Secondly, the regional war in

\footnotetext{
${ }^{13}$ Michael Meyer, The year that changed the world: the untold story behind the fall of the Berlin Wall (Simon and Schuster, 2009)

${ }^{14}$ Elspeth, Guild et al. New Approaches, Alternative Avenues and Means of Access to Asylum Procedures for Persons Seeking International Protection (CEPS Liberty and Security in Europe No. 77 Brussels 2015)

${ }^{15}$ European Union, Convention Implementing the Schengen Agreement of 14 June 1985 between the Governments of the States of the Benelux Economic Union, the Federal Republic of Germany and the French Republic, on the Gradual Abolition of Checks at their Common Borders ("Schengen Implementation Agreement"), 19 June 1990.

${ }^{16}$ European Union, Convention Determining the State Responsible for Examining Applications for Asylum lodged in one of the Member States of the European Communities ("Dublin Convention"), 15 June 1990, OJ [1997] C 254/1.

${ }^{17}$ Al-Ali, Nadje, Richard Black, and Khalid Koser. "Refugees and transnationalism: the experience of Bosnians and Eritreans in Europe." Journal of Ethnic and Migration studies 27.4 (2001): 615-634.
} 
Syria-Iraq from 2011 has tested the CEAS built on the basis of the Yugoslavia experience, and in many cases found it wanting. The 2016 reconsideration of EU solidarity among the Member States and towards refugees is resulting in substantial changes, including as suggested by Goodwin-Gill, the need for "more Europe" to compensate for the shortcomings of the system. It is important to remember this larger picture since the institutionalisation of the CEAS has tended to blur the issues. The EU's engagement with refugees did not start with an overwhelming obligation to ensure that the international protection obligations of the Member States were incorporated into the EU project, but rather as a side issue to the abolition of intra-Member State border controls on the movement of persons. Refugees were a minor irritant difficult to resolve only because of the scale antagonism of various interior ministries in some Member States to the reception of refugees on their territory. The big issue for the Schengen area was ensuring confidence of all the participating states in the propriety of external border controls on persons - the over 320 million third country nationals who enter the EU every year, according to the EU's border agency, FRONTEX. Refugees and asylum seekers have rarely exceed 1 million a year, though state responsibilities towards them are of an entirely different nature than to the 320 million plus third country national visitors to the EU.

The integrity of the CEAS was challenged by its very basis, the Dublin system of allocation of responsibility for asylum seekers. ${ }^{18}$ This first element of the system which took shape, first in the CISA and then the Dublin Agreement, is still referred to by institutional actors in 2016 as a 'cornerstone' of the CEAS. But as an allocation system, the main criterion for responsibility to receive, care for and determine asylum applications is territorial - the state in which the asylum seeker first arrived in the EU. The consequences of the system for border states have been particularly noticeable in 2014 -2015. A integral part of the Dublin system is the principle that the asylum seeker only has one chance to make his or her asylum application and in a system designed by the Member States which will determine which Member State receives that application. The creation of a database of the fingerprints of all asylum seekers and persons apprehended irregularly crossing the external borders of the EU (EURODAC) helped identify where any specific individual should be sent. That the system was based on the capacity of Member States to keep asylum seekers within their borders when border controls among the Schengen states had been abolished never worried the policy makers. In theory, asylum seekers would be sent back to where they 'ought' to be no matter how many times they went somewhere else. Asylum seekers themselves developed a profound distrust of the Dublin system and many refused to be fingerprinted, sought to avoid fingerprinting and feared coercive fingerprinting because of what they feared the outcome will be. ${ }^{19}$ The fact that, according to the EASO, only $3 \%$ of asylum seekers are ever actually sent from one Member State to another under the Dublin system is irrelevant to the terror which the system seems to inspire in asylum seekers. ${ }^{20}$

This fear is not necessarily ill-founded. If an individual only gets one chance to make an asylum application, then he or she really wants to make it to the country where he or she wants to live. This may be determined by the presence of family members, close or distant, fellow country people (or their absence where political divisions are intense and new arrivals fear informers among the resident fellow country people, interpreters etc), reputation, language and colonial links etc. At the

\footnotetext{
18 Violeta Moreno-Lax, 'Dismantling the Dublin system: MSS v. Belgium and Greece' EJML (2012) 1-31.

${ }^{19}$ Cathryn Costello, The Human Rights of Migrants in European Law (OUP 2016).

${ }^{20}$ EASO, Annual Report on the Situation of Asylum in the European Union 2014 (EASO, Brussels 2015) 87
} 
heart of the legitimacy problem of the CEAS has been the differential outcomes for refugees in EU Member States. This is the issue to which Goodwin-Gill addressed his proposal for a new agency or institution competent to make asylum decisions for all Member States. I will take two points of comparison - the UNHCR statistics published in 1999 - the year of the commencement of EU competence for asylum - and 2014, the year when the second phase of the CEAS had been adopted. If the CEAS was operating to provide a fair and equitable consideration of all asylum applications in the EU then one ought to see a convergence of the outcomes for asylum seekers from the same countries. Further, it is worth noting that over that 15 year period, three countries of origin of asylum seekers (Afghanistan, Iran, Iraq) have continued to be important sources of asylum seekers in the EU. While attention is currently focused on Syrian refugees who are a fairly new category, the other three - Afghans, Iraqis and Iranians - are fairly consistent. The overall picture in 1999 looked like this according to UNHCR.

Refugee Recognition Rates by Selected Member State and Country of Origin: $1998^{21}$

Afghanistan

\begin{tabular}{|l|l|l|}
\hline Member State & \% of applications & \% given protection \\
\hline Germany & 18.8 & 34 \\
\hline UK & 18.1 & 95 \\
\hline Netherlands & 17.6 & 57 \\
\hline Austria & 14.6 & 16 \\
\hline Denmark & 4.4 & 60 \\
\hline
\end{tabular}

Iran

\begin{tabular}{|l|l|l|}
\hline Member State & \% of applications & \% given protection \\
\hline UK & 19.1 & 77 \\
\hline Germany & 18.1 & 21 \\
\hline Belgium & 11.8 & N/a \\
\hline Austria & 9.5 & 10 \\
\hline Netherlands & 9.4 & 24 \\
\hline
\end{tabular}

Iraq

\begin{tabular}{|l|l|l|}
\hline Member State & $\%$ of applications & \\
& \% given protection \\
\hline
\end{tabular}

\footnotetext{
${ }^{21}$ Source: UNHCR Statistical Yearbook 1999.

22 Made in the EU in 2000.

${ }^{23}$ Made in the EU in 2000.
} 


\begin{tabular}{|l|l|l|}
\hline Germany & 33.8 & 37 \\
\hline UK & 20.4 & 92 \\
\hline Sweden & 10.1 & 75 \\
\hline Netherlands & 8.0 & 50 \\
\hline Austria & 6.8 & 3 \\
\hline
\end{tabular}

The statistics provided have a time gap - the application rates are for the year 2000, the recognition rates are for 1998. This is the result of a lack of more precise data on recognition rates available from UNHCR. Nonetheless, the consistency of the sending countries and the lack of substantial positive developments in them may mean that when the applications made in 2000 were considered they should enjoy about the same rate of recognition. The variations in recognition rates among Member States are astonishing. Taking the example of Iraq, the second most common source of refugees in Europe, the UK has a recognition rate of $92 \%$ while Austria's is $3 \%$ - yet both countries are in the top five EU states receiving asylum seekers from Iraq.

95\% of Afghanis whose applications were determined in the UK received protection, though the UK accounted for $18.1 \%$ of the EU applications. Austria, on the other hand, provided protection to $16 \%$ of Afghanis applying for asylum while it was responsible for $14.6 \%$ of EU applications. Turning to Iran, again the UK and Austria represented the widest divergence on protection: $77 \%$ of Iranians getting protection in the former and $10 \%$ in the latter. Yet, in 2000, 19.1\% of Iranians seeking protection in the EU did so in the UK while 9.5\% did so in Austria. Another odd aspect of these figures is that the 1998 recognition rate does not seem to have had any substantial effect on the choice of EU state in which to apply for asylum make by the individual asylum seeker.

The institutional framework of the CEAS has been built around the sensitivities of the Member States in respect of their sovereign entitlement to determine who should receive protection on their territory consistent with their duty of non-refoulement. Notwithstanding the common framework of the Refugee Convention, the Member States have clung to their different understandings of their international commitments as demonstrated in the 1999 UK House of Lords decision in Adan and Ors ${ }^{25}$ where the issue boiled down to a profound difference of interpretation of Refugee Convention obligations between France, Germany and the UK, (with UNHCR intervening) regarding agents of persecution (state or non-state actors). The solution adopted by the House of Lords was national UK law interprets the Convention in one way, the others differently so the UK will follow its own route (and the others can do as they wish). The issue shifted to the EU level with the new CEAS competence and was resolved in the Qualification Directive. ${ }^{26}$ Yet, as Goodwin-Gill stresses, the

\footnotetext{
${ }^{24}$ Made in the EU in 2000.

${ }^{25} R$ v. Secretary of State for the Home Department, Ex parte Adan and Others, United Kingdom: Court of Appeal (England and Wales) [1998] UKHL 15.

${ }^{26}$ European Union, Council of the European Union, Council Directive 2004/83/EC of 29 April 2004 on Minimum Standards for the Qualification and Status of Third Country Nationals or Stateless Persons as Refugees or as Persons Who Otherwise Need International Protection and the Content of the Protection Granted OJ [2004] L 304/12-304/23 and re-cast European Union: Council of the European Union, Directive 2011/95/EU of the
} 
legislative framework is not enough to result in common outcomes. A strong institutional framework is need to prevent unjustified variations.

The response of the EU institutions, once given competence to design the CEAS, was to focus on minimum standards - setting a base line which all Member States were obliged to respect as regards in particular, reception conditions, qualification as a refugee or beneficiary of international protection and procedures. These were set out in the first phase of the CEAS, and in 2013 the second phase moved to common standards. The first phase measures were all adopted by 2005 and had to be transposed into national law within two year deadlines. One of the key measures, an accompaniment to the Dublin allocation system was the minimum and now common standards on reception conditions. All Member States were obliged first to provide minimum reception conditions for asylum seekers (including those subject to a Dublin decision) and secondly common minimum reception conditions. This has proven the Achilles heel of the system with many Member States failing to live up to their obligations. ${ }^{27}$ Greece fell out of the Dublin system in 2012 because of its flagrant failure to provide reception conditions to asylum seekers. From January 2012 when the European Court of Human Rights handed down its judgment in MSS v Belgium and Greece Dublin transfers back to Greece were stopped. ${ }^{28}$ The CJEU followed up later that year with a similar judgment against Greece on account of the appalling conditions in which asylum seekers have to live in Greece. Neither of these judgments nor the efforts of EASO to assist the Greek authorities to create reception capacity has come anywhere near resolving the intransigence of the Greek authorities against providing reception conditions to asylum seekers. The movement of Syrian and Iraqi refugees through Greece and the western Balkans has highlighted the obvious - neither Greece nor any other country in the western Balkans want the refugees to stop in their countries. Only intense pressure from other EU states resulted in the closing of the Balkan route in January 2016 leaving many people stranded along the way. ${ }^{29}$

What are the outcomes? Taking the same three countries of origin of asylum seekers in the EU in 2013 as those examined in 1998 (above), Iraq, Afghanistan and Iran one needs to look at the outcomes fifteen years after the establishment of the CEAS designed to provide a common single asylum system in the EU 28 to determine whether it is fair and equitable.

\section{Refugee Recognition Rates by Selected Member State and Country of Origin: 2013/2014}

Afghanistan

\begin{tabular}{|l|lc|l|}
\hline Member State & $\begin{array}{l}\% \quad \text { of } \\
\text { applications }^{31}\end{array}$ & (EU) & \% given protection \\
\hline
\end{tabular}

European Parliament and of the Council of 13 December 2011 on standards for the qualification of thirdcountry nationals or stateless persons as beneficiaries of international protection, for a uniform status for refugees or for persons eligible for subsidiary protection, and for the content of the protection granted (recast) 20 December 2011, OJ [2011] L.337/9.

27 The problem is that if Member States do not provide the agreed standards of reception, refugees will move to antoher Member State where they can access reception conditions.

${ }^{28}$ MSS v Belgium and Greece [2011] ECtHR 108.

${ }^{29}$ Patrick Kingsley, 'Balkan countries shut borders as attention turns to new refugee routes' (Guardian, 9 March 2016).

30 Source: UNHCR Statistical Yearbook 2014.

${ }^{31}$ EUROSTAT Asylum Quarterly report 9 December 2015. 


\begin{tabular}{|l|l|l|}
\hline Germany & 7 & 67 \\
\hline UK & 8 & 14 \\
\hline Netherlands & 2 & 50 \\
\hline Austria & 25 & 98 \\
\hline Denmark & 6 & 37 \\
\hline
\end{tabular}

Iran

\begin{tabular}{|l|l|l|}
\hline Member State & \% of applications & \% given protection \\
\hline UK & 8 & 57 \\
\hline Germany & No longer in the top 5 & 73 \\
\hline Belgium & No longer in the top 5 & 61 \\
\hline Austria & 3 & 97 \\
\hline Netherlands & No longer in the top 5 & 45 \\
\hline
\end{tabular}

Iraq
\begin{tabular}{|l|l|l|}
\hline Member State & $\begin{array}{l}\% \text { of applications } \\
(2014)^{33}\end{array}$ & $\%$ given protection \\
\hline Germany & 6 & 87 \\
\hline UK & No longer in top 6 & 37 \\
\hline Sweden & 10 & 52 \\
\hline Netherlands & 4 & 42 \\
\hline Austria & 19 & 97 \\
\hline
\end{tabular}

After 15 years of designing and implementing the CEAS the variations in protection rates are almost as shocking as in 1998. For Iraqis, only $37 \%$ receive protection in the UK while $97 \%$ of those who seek asylum in Austria receive protection. For Afghans, again the UK and Austria form the two extremes protection rates of $14 \%$ in the UK and $98 \%$ in Austria. Iranians fare poorly in the Netherlands with a $45 \%$ recognition rate but well in Austria with a $97 \%$ recognition rate. All of the figures are for new applications or first instance decisions.

${ }^{32}$ EUROSTAT Asylum Quarterly report 9 December 2015.

${ }^{33}$ EUROSTAT Asylum Quarterly report 9 December 2015. 
EASO also recognises the issue of differential recognition rates of nationals from the same countries, in particular ones with on-going civil or regional wars within their borders. In its Annual Report on the Situation of Asylum in the European Union 2014"34 it states "The same chart [wide disparity in recognition rates among EU+ countries for some citizenships] shows that the recognition rates of Iraqi and Afghan applicants varied prominently and ranged from $13 \%$ to $94 \%$ for the first and $20 \%$ to 95\% for the latter group of applicants." (section 2.4) However, it sought to excuse this variation stating "It should be noted that the scattering does not necessarily point towards a lack of harmonisation across the EU+ countries in terms of decision-making practices, but may rather indicate different profiles of applicants who have the same citizenship (eg such as states favoured as destination countries by specific ethnic minorities such as Chechens or Kurds). Only a case-by-case analysis of decisions would determine real differences in practice or policy among states on similar types of claims." Yet, in the same report, further on in EASO's analysis of the situation in Afghanistan it states "These developments culminated in 2014 being the most deadly year for civilians in the recent conflict so far: UNAMA (United Nationals Assistance Mission to Afghanistan) documented 3,699 civilian deaths about 6,849 injuries a $22 \%$ rise compared to the previous year." (section 2.5.7). THE CEAS procedures directive requires that asylum seekers whose applications are rejected have the right to appeal to a judicial or administrative authority. Yet according to EASO in its 2014 Annual Report in some Member States success at the appeal stage was 50\% (Bulgaria, Italy and Finland) - an indication of serious problems at the first instance decision making stage - but close to zero in five (unspecified) Member States. Syrians had the best success rate on appeal at $71 \%$ according to EASO but Afghans had only a $42 \%$ success rate. The rate dropped again for Iranians to $41 \%$. Goodwin-Gill's proposed new operational competence for asylum determination will need a consistent and fair appeal structure to fulfil its objectives.

The Dublin system of allocation of responsibility for asylum seekers does not resolve the fairness issues either. According to EASO, in 2014 65\% of Dublin cases were take back - that is where an asylum seeker has made an asylum application elsewhere in the EU and $35 \%$ were take charge cases - where the person has not applied for asylum elsewhere but the Member States has reason to believe that he or she is the responsibility of another Member State under the Dublin criteria. Interestingly, according to EASO the majority of the take charge requests $(60 \%)$ were on the basis that the asylum seeker had documentation indicating legal entry in another Member State, the next most important category was family reunion (22\%). This leaves only $12 \%$ of the take charge cases being based on irregularly entry into the EU via the requested state. What this means is that those asylum seekers who arrive irregularly in the EU refusing to make an asylum application and travelling as quickly as possible on to the place where the person wants to make his or her asylum application is a successful strategy for $88 \%$ of asylum seekers. Their applications will be considered in the state where they apply for asylum. One might call this successful "self re-location". Goodwin-Gill's determination system will also need a system whereby beneficiaries of international protection are entitled to go to the Member State where they have links. Further, mutual recognition by all Member States of the status of beneficiary of international protection coupled with a right to move from one Member State to another will be key to ensuring that all secondary movement of refugees takes place within a coherent, legal system.

${ }^{34}$ EASO, Annual Report on the Situation of Asylum in the European Union 2014, Luxembourg 2015. 
Excellent quality and reliable country of origin information (COI) is critical to more justice for asylum seekers into the EU'S CEAS decision making and outcomes. One argument goes that if all the Member States used the same $\mathrm{COI}$ as a starting place in the determination of asylum applications, outcomes might be more coherent. There would, of course, need to be the opportunity for an asylum applicant or his or her counsel to present further information or information which contradicts the standard pack but a common starting place might be helpful for decision makers trying to determine what is actually going on in a country of origin in order to make a decision on the actual need for protection of the person in front of them.

This may seem self evident and even possibly a fairly simple matter involving allocation of translation services, something of which EU institutions are masters. But this has not been the case. While EASO states in its Annual Report 2014 that "availability and an appropriate use of country of origin information (COI) are crucial for well informed, fair and well-reasoned asylum decisions. In 2014, Member States and EASO continued to aim at improving the quality, efficiency and accessibility of $\mathrm{COI}$ by developing new methodologies and products and further developing databases." (section 4.10). The source of the COI problem can be found exactly here - Member States and EASO - it would seem that there are a number of Member States which have well developed bureaux which produce $\mathrm{COI}$ and they are not interested or willing to dismantle them in favour of an EASO centralised system. Further, while all Member States COI units are willing to share some information with EASO, it is far from clear that they share all or indeed the most sensitive. As these units often have links with other parts of government and receive briefings from intelligence branches of their administrations not all information which they have is capable of being shared. Indeed, no doubt it could be dangerous for asylum seekers if such information were to be shared as it is not always of the quality necessary for judicial decision making. So the range of information used by national $\mathrm{COI}$ units is not always consistent as regards sources and the value placed on those sources. In light of the countries chosen for networks and the continuing disparities in recognition rates, this approach does not appear to have borne substantial fruit yet.

Goodwin-Gill called for a new agency to include competence not only to implement Member States obligations on asylum but also on immigration "precisely because the arrival of those in an irregular situation, whether directly or following interception or rescue at sea, presents Member States with legal and practical challenges" which require a Union response. ${ }^{35}$ The Dublin data of EASO indicate just how many people in need of international protection seek to avoid applying for asylum in the first country they arrive in so that they can make an application in the country where they wish their asylum application to be considered. While some Member States, at the time of writing Germany and Sweden in particular, claim that all asylum seekers want to make their applications in their countries, the EUROSTAT asylum statistics indicate otherwise. In the EUROSTAT asylum report on $3^{\text {rd }}$ quarter 2015 issued on 9 December 2015, on the basis of information provided by the Member States' statistical authorities, it calculated that $26 \%$ of all first asylum applications presented in the EU were made in each of Germany and Hungary in that quarter followed by Sweden which accounted for $10 \%$ of the total number. Of course the size of the countries is not comparable -

\footnotetext{
${ }^{35}$ Guy Goodwin Gill 'Regulating “Irregular" Migration: International Obligations and International Responsibilities', Keynote Address to the International Workshop, National and Kapodistrian University of Athens Faculty of Law, Friday, 20 March 2015.
} 
Germany with a population of 80 million and Hungary and Sweden with populations of around 9.6 million.

However one looks at these figures, it is evident that asylum seekers, who at the time of writing mainly arrive by land and sea (not air as they cannot get flights on account of carrier sanctions against the airline in the event that an airline carries persons without passports and valid Schengen visas which in any event cannot be issued for international protection purposes). ${ }^{36}$ This means that the point of entry into the EU is primarily not Germany, Hungary (though this may be an important entry point for asylum seekers from the Western Balkans who do not require Schengen visas for entry into the EU) or Sweden. The EU's Fundamental Rights Agency, the FRA, has been publishing weekly data collected on the situation of persons in need of international protection at the request of the Commission since the start of the 2015 so-called refugee crisis. At the time of writing the most recently available report covers the week 16 - 20 November 2015 and describes the situation eight countries: Austria, Bulgaria, Croatia, Germany, Greece, Hungary, Italy and Slovenia. Austria, Germany, and Hungary consider themselves to be destination countries, even though there is much movement from Austria towards Germany and Sweden. The situation in Hungary is fairly mixed - in the end it is not entirely clear just how many people actually pursue their asylum applications there. Italy is also a country of asylum and transit for many asylum seekers who arrive there. The other countries are primarily countries of transit. The FRA report covers new arrivals focusing on where and why people become stranded in one country or another. This weekly report is particularly illuminating on the practices of Macedonia and Greece at their common border - in particular the main crossing point at Idomeni - and how people become stranded in Greece when they are trying to move onwards and northwards through Europe. But this is not the only border crossing point which the report singles out as problematic. Croatia, Italy and Slovenia are noted as refusing entry to people coming from countries which they have designated as 'not affected by war'. The FRA sources indicate that they aware of particular of push backs of new arrivals by Croatian border guards where people could not prove they were from Syria, Afghanistan or Iraq. On the other hand, transit through Croatia, according to the report, has become faster. It seems that the Croatian authorities acquiesce to the perceived interests of people in transit to ensure they get to where they are trying to go rather than convince them that they really want to stay and apply for asylum in Croatia. ${ }^{37}$

The FRA reports focus on reception conditions (by and large appalling almost everywhere) child protection (limited and over stretched) and the legal, social and policy response. In this third category, the FRA reports pay particular attention to anti foreigner backlash after the terrorist attacks in Paris on 13 November 2015 and any impact this seems to be having in the countries under consideration (surprisingly little according to the sources in all the countries). However, both Germany and Slovenia planned to use more accelerated procedures in particular against nationals of Western Balkan and north African countries. What the report reveals is the degree of consensus at least at the national level that people on the move are better off moving that being blocked. The blocking efforts seem to be the exception rather than the rule and they seem to be sporadic and fairly ad hoc. The only country which was reported as using criminal sanctions in substantial

\footnotetext{
${ }^{36}$ Sophie Scholten The Privatisation of Immigration Control Through Carrier Sanctions: The Role of Private Transport Companies in Dutch and British Immigration Control (Brill, 2015).

${ }^{37}$ EU Fundamental Rights Agency 'Fundamental rights at land borders: findings from slected European Union broder crossing points' (FRA, Vienna 2015).
} 
quantities was Hungary, which has made it a criminal offence to carry out an unauthorised border crossing (mainly ducking under or climbing over the Hungarian Serbian border fence). In the one week period covered by the report, 21 criminal trials were held and 17 people were convicted of the offence which resulted in penalties of expulsion from Hungary and re-entry bans of one to three years. Again, Hungary was the only country in respect of which the FRA sources indicated that the criminal offences of facilitation of irregular entry or stay were being used. FRONTEX reports however that in Q3 2015 border guards reported that they had identified 3,166 facilitators of irregular entry, a $13 \%$ increase over the previous year. ${ }^{38}$

Finally, if one takes into account the information produced by the EU external border agency, FRONTEX, $3^{\text {rd }}$ quarter 2015 was a busy time. According to FRONTEX's FRAN report on the situation at the EU external borders, there were 617,412 irregular border crossings of the EU's external borders in that quarter. ${ }^{39}$ This compares with 170,155 in Q2 2015 and 80,109 a year earlier Q3 2014..$^{40}$ So according to FRONTEX there is a lot of unregulated border crossing into (and possibly out of) the EU taking place - a fact which is supported by the media reports of people entering and exiting and reentering the EU through the sea and land borders of the Western Balkan states in a highly erratic manner. Yet, as the FRA report reveals, most people in need of international protection crossing into and out of the EU for instance at the Greek Macedonian border, do so at the designated crossing point Idonemi. There are no reports of people in need of international protection wandering through the Greek Albanian mountains. That the people crossing irregularly at these regular crossing points are in need of international protection is indicated by the FRONTEX figures: in Q3 2015 only 32,868 persons were refused admission to the EU. So of the 617,412 irregular border crossings, only a tiny proportion were subject to a refusal of entry decision. Further, FRONTEX reports that border guards notified it of 283,353 instances of irregular stay identified in Q3 2015. ${ }^{41}$ There is no indication of how many of these people subsequently applied for asylum - perhaps having been identified as irregularly present while on route to the country where they planned to seek asylum.

Before leaving this subject, it is worth recalling that again according to FRONTEX, in 2014, 320 million third country nationals subject to immigration controls turned up at the EU's external borders. In view of the pressure of numbers, again according to FRONTEX, a border guard has 12 seconds in which to make a decision to admit or refuse admission (or refer to secondary examination) a passenger. ${ }^{42}$ On 16 December 2015, European Tourism Day, ${ }^{43}$ Slawomir Tokarski Acting Director Innovation and Advanced Manufacturing, DG GROWTH, European Commission made a speech in support of the travel industry stating that tourism contributes up to $10 \%$ of EU GDP and called for more third country nationals to be welcome in the EU (as tourists).The figures are sufficiently astonishing as to merit no further comment at this time. Instead I wish to return to the need for EMPA - the European Migration and Protection Agency.

\section{Conclusions}

\footnotetext{
${ }^{38}$ FRONTEX 'Third Quarter 2015 Risk Analysis' (FRONTEX, Warsaw, 2015).

${ }^{39}$ FRONTEX, 'Annual Risk Analysis' (FRONTEX, Warsaw, 2015).

${ }^{40}$ FRONTEX 'Third Quarter 2015 Risk Analysis' (FRONTEX, Warsaw, 2015).

${ }^{41}$ FRONTEX 'Third Quarter 2015 Risk Analysis' (FRONTEX, Warsaw, 2015).

42 FRONTEX '12 Seconds to Decide: In search of excellence, FRONTEX and the principle of best practice' (FRONTEX, Warsaw, 2015).

${ }^{43}$ Opening Remarks, European Tourism Day, Charlemagne Building, Brussels, 10 December 2015.
} 
EU border controls must be carried out with full respect for the Member States obligations of international protection not only as a duty in international and regional human rights and refugee law but also as part of EU law (Articles 3 and 3A Schengen Borders Code ${ }^{44}$ and Articles 18 and $19 \mathrm{EU}$ Charter of Fundamental Rights). It seems, from the events of 2015-16, that the EU is having rather a lot of difficulty in actually delivering on its obligations international, regional and in the EU. As I have discussed in this article, 15 years of a CEAS has not resulted in a fair chance of international protection for asylum seekers in the EU. Variations across countries remain shocking and show little improvement over those 15 years that the Member States have been trying to get a truly harmonised system in place which could justify the EU claim to the right to allocate where asylum seekers can make their claims according to the Member States' own criteria and mutual recognition of all negative decisions. The statistics set out in the preceding section are a stark reminder of the injustice which is being visited on refugees in the EU every day in the determination of their claims by 28 different asylum authorities which are under no obligation to have regard to the determination of similar claims made in other Member States.

Notwithstanding the creation of an ever increasing number of EU agencies with responsibilities which include asylum seekers such as EASO, the FRA and others, little progress seems actually to be taking place on the ground. The Syria/Iraq/Afghan crises which rose to the top of the political agenda in 2015 have only highlighted the current inadequacies of the system and the impotence of the existing agencies to deal with the issues of burning importance to refugees coming to Europe.

There are many options open to the EU at this juncture - the most unattractive is to blunder on continuing to claim the legal, moral and ethical legitimacy of the Dublin system (to allocate asylum seekers to states according to their own preferences) which has brought such misery to so many people. Another option would be to strengthen the powers of some of the existing institutions such as the FRA and/or EASO providing them with real operational powers to ensure that people who need international protection get it in conditions of dignity and in accordance with their preferences. If, institutionally, these agencies are too far committed to intergovernmental approaches to their work which would hamper their capacity even to enter into real dialogue from a position of power with national authorities and insist on the correct application of the EU acquis (minus Dublin and enhanced to improve protection capacities on the ground) then the Goodwin-Gill proposal of a new agency, EMPA may be the best viable route to achieving a real and effective CEAS which is fair to asylum seekers and refugees. There are many questions and issues which would need resolution. Most important, the system would have to be truly dedicated to international protection. Any agency which became a mechanism to reduce the rates at which asylum seekers are recognised as refugees and beneficiaries of international protection to the lowest standard of any Member State would have no legitimacy. One can well see an interest in some administrative quarters for just such an outcome - an increase in refusal rates which a single institution could deliver across the EU. This must be resisted. Instead international protection would have to be the core value and driving objective of the agency and it would have to be guaranteed freedom from Member State interference. A residual competence to Member States to recognise, under national law,

\footnotetext{
${ }^{44}$ European Union: Council of the European Union, Regulation (EC) No. 562/2006 of the European Parliament and of the Council of 15 March 2006 establishing a Community Code on the rules governing the movement of persons across borders (Schengen Borders Code), 15 March 2006, OJ L. 105/1-105/32; 13.4.206, (EC) No 562/2006, available at: http://www.refworld.org/docid/47fdfb0525.html [accessed 6 February 2016]
} 
beneficiaries of international protection would need to be recognised. This would also assist in ensuring that any new agency would not start a race to the bottom as regards recognising applications as such an approach would trigger concern at the national level in some Member States and lead to a ballooning of the issue of national statuses contrary to the objective of the agency.

Other issues which would need to be resolved include the duty of the state where an asylum seeker has applied for asylum to provide reception conditions for the duration of the consideration of the application. Once the application has been determined and refugee status recognised or the grant of subsidiary protection the Member States would need to be required to recognise this status as an obligatory ground to issue a residence permit to the individual. All Member States would need to be equally bound by a favourable decision thus permitting the beneficiary an opportunity to move to that Member State where he or she wishes to live. This would ensure that unregulated secondary movements of asylum seekers would be less likely to occur as once recognised the individual would be able to move in an orderly manner.

The Goodwin-Gill institutional proposal merits serious consideration. There are many practical issues which would need to be resolved but most importantly the independence of any new agency would need to be ensured, the coherence of decisions, appeal rights and the like. Its sole duty would need to be the determination of international protection claims in the spirit of the Refugee Convention and the Member States international obligations. 